\title{
Acute Cervical Myelitis: A Rare Complication of Varicella Zoster Virus Infection
}

\author{
Akut Servikal Miyelit: Varisella Zoster Virüsünün Ender Görülen Bir Komplikasyonu
}

Keywords: Varicella zoster virus, cervical myelitis, MRI, outcome

Anahtar Kelimeler: Varisella zoster virüsü, servikal miyelit, MRG, prognoz

\section{Dear Editor,}

A 59-year-old female patient was admitted to the neurology inpatient ward due to bilateral lower extremity and left upper extremity weakness with accompanying paresthesia for almost 40 days. She also had difficulty in differentiating between urination and defecation, but otherwise did not have incontinence. Two weeks prior to the onset of her symptoms, she had developed zona zoster-related lesions on the back of the right side of her head, for which she received P.O. acyclovir for one week.

Her past medical history revealed hypertension and hypothyroidism. She had also been taking methotrexate and hydroxychloroquine for rheumatoid arthritis. Her family history was unremarkable. Neurologic examination revealed mild paraparesis ( $4 / 5$ bilaterally) with mild left upper extremity weakness (proximal 5-/5, distal 4/5). She described hypoesthesia below the left elbow and distal to L2 bilaterally. She also has saddle anesthesia. Left patellar reflex was hypoactive and plantar responses were flexor bilaterally. Before admission to our hospital, she had already been investigated with thoraco-lumbar spinal magnetic resonance imaging (MRI), which revealed spondylosis and mild disc bulging at various levels. Also, an electromyographic investigation disclosed bilateral mild L2-3 radicular compression and left carpal tunnel syndrome findings. Upon admission, we ordered cervical MRI due to zona zoster history at the C2 dermatome. Imaging findings were consistent with a cervical T2W hyperintense lesion, involving roughly three vertebral segments, with contrast enhancement (Figure 1A, B, C, D). Cerebrospinal fluid (CSF) contained $41 \mathrm{mg} / \mathrm{dl}$ protein and $68 \mathrm{mg} / \mathrm{dl}$ glucose. No white blood cells or microorganisms were detected. CSF immunoassay revealed negative anti-Varicella Zoster virus (VZV) $\mathrm{IgM}$. However, the anti-VZV IgG antibody level was > $5000 \mathrm{IU} / \mathrm{l}$, which was consistent with intrathecal synthesis. The patient was referred to the infectious diseases department; no further treatment was recommended. She received $1 \mathrm{~g}$ IV methylprednisolone for 3 days. On follow-up, her walking difficulty recovered and the severity of paresthesia decreased.

The incidence of zona zoster is about 3-4/1000 patient-years (1). The reactivated virus can invade the nervous system and lead to meningitis, encephalitis, myelitis, radiculitis, and polyneuritis. Very few cases of VZV myelitis have been reported in the literature (2). It is a rare complication that typically occurs within 3 months after rash (usually, but not invariably at the same dermatomal level). This is usually a self-limiting, monophasic disorder with or without sensory involvement and sphincter problems (3). Myelopathy involves the thoracic segment of the spine in $>80 \%$ of cases. In patients who are immunocompromised (involving patients on immunomodulatory treatment), it can be progressive and fatal. Pathologic analysis of autopsy cases has demonstrated tissue necrosis, inflammatory cell infiltration, vasculitis, thrombosis, and Cowdry a type inclusion bodies. MRI typically reveals a T2 hyperintense lesion with $\mathrm{T} 1$ contrast enhancement. It can be diagnosed by several methods, the most common of which are the presence of VZV DNA or increased titer of anti-VZV IgG in CSF. DNA is more detectable during the first week, whereas antibody is more detectable later on (2). Although treatment with IV acyclovir or other antiviral agents is recommended, it does not alter outcomes significantly, which are usually good in most immunocompetent patients and also half of immunocompromised

\footnotetext{
Address for Correspondence/Yazışma Adresi: Neşe Dericioğlu MD, Hacettepe University Faculty of Medicine, Department of Neurology, Ankara, Turkey Phone: +90 5322211269 E-mail: nesedr@hacettepe.edu.tr ORCID: orcid.org/0000-0003-2465-3017

Received/Geliş Tarihi: 03.11.2019 Accepted/Kabul Tarihi: 23.01.2020

${ }^{\oplus}$ Copyright 2020 by Turkish Neurological Society

Turkish Journal of Neurology published by Galenos Publishing House.
} 

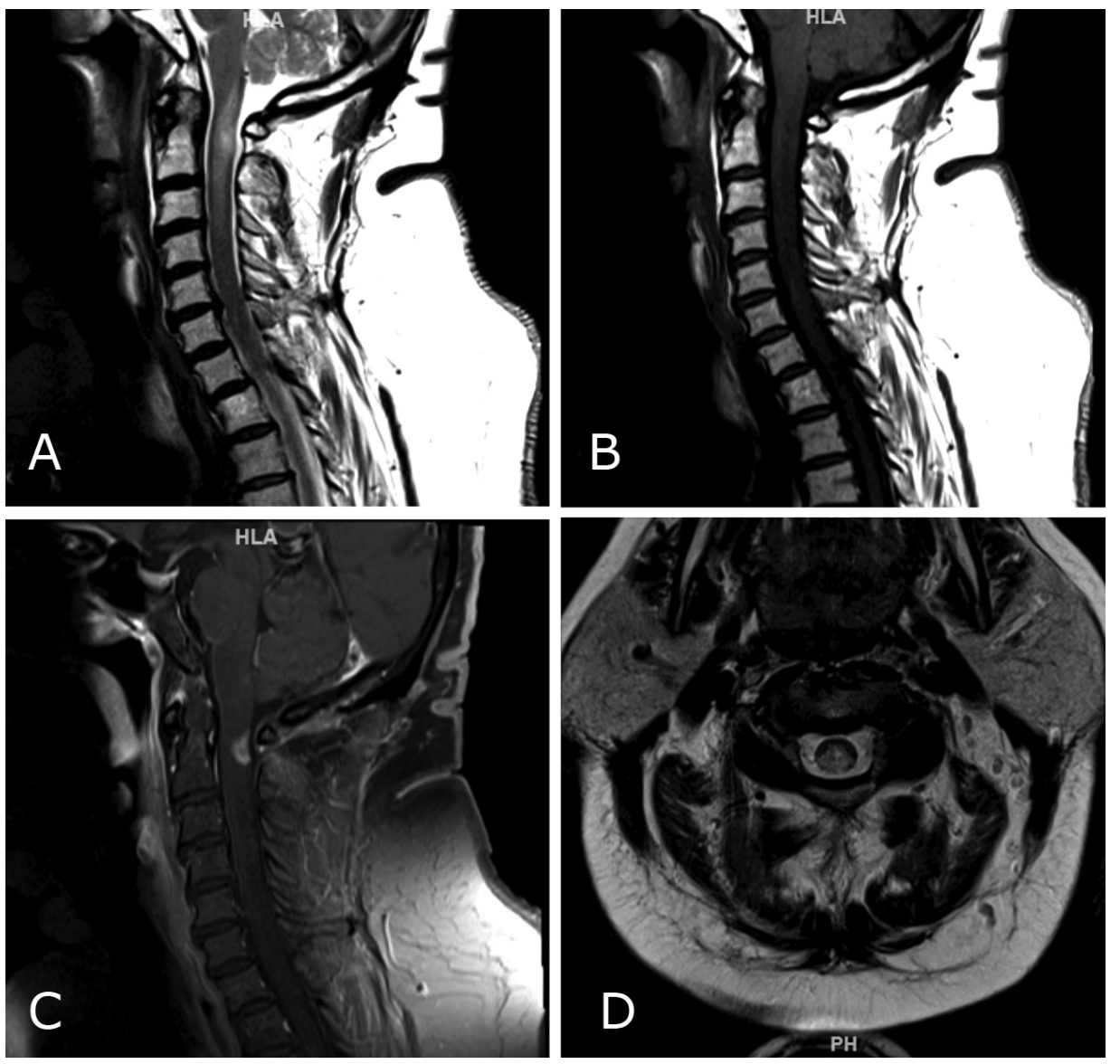

Figure 1. VZV-related lesion of the cervical spinal cord. A) T2W sagittal image demonstrating hyperintense appearance between lower medulla and upper border of C4. B) The lesion appears hypointense on T1W sequences. C) Contrast enhancement involving posterior aspect of the cord at the level of $\mathrm{C} 2$. D) T2W axial image at the level of $\mathrm{C} 2$ indicating almost symmetrical hyperintense lesion located centrally and more posteriorly

VZV: Varicella Zoster virus

cases (2). Our patient was receiving immunosuppressive therapy so she was immunocompromised. However, she recovered almost completely, even without IV acyclovir. If a patient develops signs and symptoms of spinal cord involvement after zoster, VZV myelitis should be kept in mind.

Ethics

Informed Consent: Written consent was obtained from the patient.

Peer-review: Externally peer-reviewed.

\section{Authorship Contributions}

Surgical and medical practices: P.P., K.A., E.T., N.D., Concept: N.D., Design: N.D., Data collection or processing: P.P., N.D.,
Analysis or interpretation: E.T., N.D., Literature search: P.P., N.D., Writing: P.P., N.D.

Conflict of Interest: No conflict of interest was declared by the authors.

Financial Disclosure: The authors declared that this study received no financial support.

\section{References}

1. Gershon AA, Breuer J, Cohen JI, et al. Varicella zoster virus infection. Nat Rev Dis Primers 2015;1:15016.

2. Hung $\mathrm{CH}$, Chang $\mathrm{KH}$, Kuo $\mathrm{HC}$, et al. Features of varicella zoster virus myelitis and dependence on immune status. J Neurol Sci 2012;318:19-24.

3. Nagel MA, Gilden D. Complications of varicella zoster virus reactivation. Curr Opin Neurol 2013;15:439-453. 